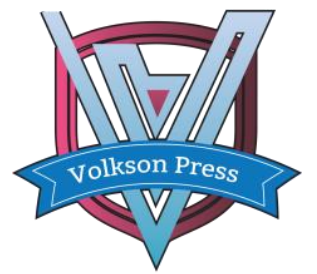

Contents List available at VOLKSON PRESS

Economics \& Management Innovations(EMI)

DOI : http://doi.org/10.26480/icemi.01.2017.413.414

\title{
Application of PPP Mode in Our National infrastructural Construction
}

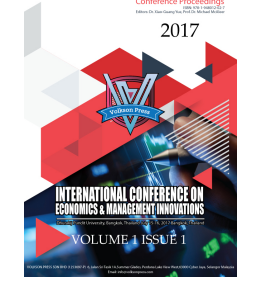

\section{Li LI, LiuboHu * , LinaXiao}

1.School of Management, Wuhan Donghu College, Wuhan, China;

Email: 4732734 @qq.com

This is an open access article distributed under the Creative Commons Attribution License, which permits unrestricted use, distribution, and reproduction in any medium, provided the original work is properly cited.

\section{ARTICLE DETAILS}

\section{Article History:}

Received 02 october 2017

Accepted 06 october 2017

Available online 11 october 2017

\begin{tabular}{lr} 
Keywords: & \\
PPP Mode; & infrastructural \\
Construction; & Application. \\
\hline
\end{tabular}

\section{ABSTRACT}

This paper introduces the application of PPP mode in our national infrastructural construction, analyzes problems in the actual operation of PPP mode and puts forward a couple of corresponding strategies. Firstly, Standardize PPP project process management, improve its efficiency; Secondly, improve governmental functions; Thirdly, Review of PPP project experiences; Lastly, Construct a complete PPP legal system.

\section{Introduction}

Since 2014, our nation economy enters into a "new normal". In local governments, efforts are strengthened to raise funds for public infrastructural construction, and subsequently there are local debt crises which gain universal attentions and criticisms both domestically and abroad. The pass of new Budge Law in August, 2014 and the enactment of Proposals upon Strengthening Management of Local Government Debt in October urge the application and promotion of PPP mode in infrastructural construction.

In September, 2014, the first PPP document in Ministry of Finance, Notification of Matters upon Promotion and Application of Government \& Social Capital Cooperation Mode, Fiance No. [2014]76 came into being. PPP mode serves as an significant means for Ministry of Finance, NDRC(National Development and Reform Commission) and other institutions to solve the funding of urban construction, which is a research focus for all sectors of society.

\section{Conception of PPP Mode}

PPP , an acronym for Public, Private, Partnership, is often interpreted as a cooperation of the public and private, or of government and social capital. Its purpose is to provide public services and products to society. From Instructions on Promotion of Government \& Social Capital Cooperation in Public Services Area, issued by General Office of the State Council of the People's Republic of China, No. [2015 \42, Ministry of Finance, NDRC, and PBOC(the People's Bank of China) point out that government \& social capital cooperative mode is a significant innovation for public service supply mechanism, which means that government would adopt a competitive way to carefully select the right social capital with proper investment and operation management and capabilities, and in accordance with the principle of equal consultation, the two parties would sign a contract to specify respective responsibilities, rights and interests.

\section{PPP Mode' Procedures}

PPP Mode' Procedures consists of the following steps:1, Preliminary preparation stage: select an item and make a feasibility research of it, then choose the right private investment institute through an open bidding, negotiate, sign contracts and set up a project company(SPV) to take charge of the project development. 2, Construction and operation stage: discussions should be made upon project technology, funds, constructions and other issues. As agreed in contract, SPV is supposed to take responsible for project construction and operation.
3,Transferring\&Termination stage: according to the duration period stipulated in contract, at the end of franchise term, the project and its operation right should be transferred from SPV project company to government, and liquidation work should be done by project company. After transferring, all the relevant businesses should be terminated from the project company.

\begin{tabular}{|c|c|c|}
\hline Item selection & \multicolumn{1}{|c|}{$\begin{array}{c}\text { Private investment } \\
\text { selection } \\
\text { establishment }\end{array}$} \\
\hline \begin{tabular}{c|c|} 
project \\
transferring
\end{tabular} & $\begin{array}{c}\text { project } \\
\text { operation }\end{array}$ & $\begin{array}{c}\text {-Project } \\
\text { development }\end{array}$ \\
\hline
\end{tabular}

Fig1 General procedures for PPP Mode

\section{Issues of PPP Mode Application in Our Country}

\subsection{Non-standard operation of PPP project}

In the first place, this non-standard operation is manifested in the deficiency of operational transparency for that many items fail to invite bid; secondly, the operative personnel are not professional, and the public service personnel in charge of PPP mode change frequently, plus, the stress upon relevant experiences in the process of consultancy selection is not sufficient:; and what is more, the project conditions are not properly designed; lastly, the project schedule is arranged too tight, and many essential preparatory works are omitted or the works are not done enough.

\subsection{Governmental authority excesses or insufficiency}

In order to develop municipal public utility industry, some local governments with little acquaintance of relevant laws and regulations fail to carefully assess the item feasibility, and frequently offer investors the financial guarantees against laws in process of investment attraction, including the national treatment, indiscreet promises of tax reduction and tax exemption beyond their approving right. For some items, there are no adequate market researches and opinion polls prior to project construction and development; some items have no public price hearings; the project abortions or failures incurred by governmental authority excesses and insufficiency in dealing with the preliminary works commonly happen. 
4.3 PPP Mode appears too complex, time-consuming and is hard to promote.

Up to the end of March, 2017, there are 12287 items in National PPP Integrative Information Platform Database, among which 1729 items enter into the implementation stage, accounting for $14.07 \%$. According to statistics, it generally takes more than 200 days for a PPP item from launching to PPP contract signing. The complexity of PPP procedure serves as one of the reasons to cause time consumption; other reasons that make PPP promotion and implementation slow include a wait-and-see attitude toward PPP from government and social capitals.

\subsection{PPP mode lacks of legal security.}

First, at present, our country has not yet promulgated a set of laws and regulations exclusively for government \& social capitals cooperation. The legislature basis for PPP laws remain very low. Although the State Council and the six ministries jointly issued the "Measures for the Administration of Infrastructure and Public Sector Franchising" in April 2015, it was only one of the PPP models and could not cover all PPP models. Furthermore, since PPP legislature level is not high, there are mostly department's rules and local laws. Any enactment, modification and reinterpretation of laws or regulations could trigger changes to legitimacy of the original agreement, hence threatening the smooth construction and operation of a project and even leading to project abortion and failure.

\section{Measures to improve PPP Mode}

\subsection{Specify PPP project operation and improve its efficiency}

PPP projects involve government, social capital, construction corporations, operation \& management corporations, financial institutes, assessment agencies and other interest subjects. Therefore, the specification of project operation is an essential prerequisite to ensure an efficient cooperation of all parties. Ranging from governmental financial affordability assessment, social capital bidding invitation, market prediction, project rewarding mechanism, performance appraisal to governmental payment listed into budget and so on, all these PPP procedures require an appropriate planning, accurate prediction, information publication, and financial institutes like banks to examine and supervise over relevant steps by means of loans; On top of that, government should endeavor to cultivate a batch of professional PPP talents in areas of raising funds, financial affairs, laws, technology and so on, establish a specialized division to deal with PPP- related issues and take an in-depth research upon the actual situations of all PPP projects to ensure a proper planning, design \& deployment, specific division of labor, timely effective problem handling, and efficiency improvement while simplifying approving procedure, making the start-up of a PPP project quicker, which then reduces the time cost.

\section{2 governmental functions improvement}

Government should define its functions. First, government should establish supervision mechanism to strengthen supervision over all steps including project bidding, feasibility assessment, market prediction and set-up of SPV company. It could also actively bring in professional mechanism from a third party to monitor PPP project assessment; besides, it can utilize purchasing power parity information platform to avoid information asymmetry, rent-seeking as well as a chaos of government \& corporation contract violation; furthermore, social supervision over public rights should also be exerted and the open supervision complaining channels should be improved.

\subsection{Review of PPP project experiences \& lessons as well as its promotion}

At present, all sectors from central government and local government are working on PPP pilot or demonstration project. Currently, our national implemented PPP projects are 1729, which are a PPP goldmine. While advancing these PPP projects, more emphasis should be laid upon summarizing the experiences of past PPP projects and promoting. Sum up all the key points, difficulties, as well as the risks of each step in the process of PPP project, and make them a reference for future PPP legislature and other aspects.

\subsection{PPP legal system improvement}

PPP mode operation is a complicated systematic process, which entails scientific healthy laws to ensure its proper practice. In western counties, a set of regulations from project approval, bidding, construction, operation, risks allocation and so on are formulated to avoid the occurrence of problems in each step. Our country should expedite the progress of legislature, and could also learn the foreign legislature method to make specialized laws for a specific item. At the same time, practice, conclusions and modifications should be made according with the actual conditions of our nation. In the process of lawmaking, with bold visions and discreet argumentation, active steady project pilots could be carried out to accelerate establishment of legal systems for our national project financing.

The following requirements should be achieved for a legal security of PPP mode:

(1)raise PPP legislature level, strengthen the top-level construction concerning PPP laws, elevate PPP legislature rules to legal level and let National People's Congress (NPC) legislate laws, rather than just remain on specific department's regulations or local rules.

(2)make clear the relationship of upper laws and subordinate laws and establish complete definite legal systems in case that the project should be bankrupted or the crisis of government credit should happen, resulting from the legal conflicts of central government and local sectors.

(3)Specify and regulate PPP project operation through a complete perfect legal security system. For that government is the administrative subject, PPP mode has a public attribute and PPP agreement is considered as a civil contract, once government violates the stipulation, social capital entity should make corresponding civil remedies according to civil laws.

\section{Acknowledgement}

The research work is financiallysupported by the Youth Social Science Fo undation of Whuhan Donghu University (Research on the Role Orientation of Government Financing Platform in PPP Financing Model) Wuhan Donghu university research [2015] No. 8Document.

The research work is also financially supported by the Hubei Provincial Department of Education Humanities and Social Sciences Research Project, Project No . 16G132

\section{References}

[1] Rui LI - Research on the Application of PPP Financing Mode in Non operating Infrastructure Project [D] · Anhui University.2016(9) · 10-12.

[2] Junhao Wang, Xuanxuan Jin. Contractual relationship between government and private enterprise under the PPP model and its governance. Economics and Management Research, 2016,(3):62-68.

[3]Peiyi Guo, Fengjiao Long. Problems and Suggestions in the Process of PPP Mode Advancement [J]. Construction Economy , 2015 ( 8 ) 38:1114.

[4] Zhengxiang Zhou, Xiufang Zhang, PingZhang. Problems and Countermeasures of PPP Mode Application in New Normal[J]. China Soft Science 2015 ( 2):85-88.

[5] HongHua Cao, YanLi, Bangwen Peng. Research on Local Government Debt Risk Analysis and PPP Financing Innovation[J].Macroeconomic Management,2015 ( 3 ) :211-215.

[6] Xiong Deng. Accelerate the development and improvement of PPP mode [J]. Financial market, 2015 (5) :92-95.

[7] XU Lin , A Study on Legal Issues of French Public - Private Partnership (PPP Model) , Administrative Law Review,2016 ( 3 ) :116-127.

[8] KangJia, LinZhu, JieSun. The Exploration Effect and Practice of PPP Model in China [J]. Economic Herald, 2015 (1) :34-39. 